\title{
BIOACTIVE DAIRY INGREDIENTS FOR FOOD AND NON-FOOD APPLICATIONS
}

\author{
P.L. TAN ${ }^{\mathrm{a}}$, K.K. PEH ${ }^{\mathrm{b}}$, C.Y. GAN ${ }^{\mathrm{c}}$ and M.T. LIONG ${ }^{\mathrm{a}}$ * \\ a School of Industrial Technology, Universiti Sains Malaysia, 11800 Penang. Malaysia \\ ${ }^{\mathrm{b}}$ School of Pharmaceutical Sciences, Universiti Sains Malaysia, 11800 Penang. Malaysia \\ ${ }^{\mathrm{c}}$ Doping Control Centre, Universiti Sains Malaysia, 11800 Penang. Malaysia
}

(Received: 17 July 2012; accepted: 14 September, 2012)

\begin{abstract}
Lactobacilli and bifidobacteria are most commonly encountered in the dairy industries, either existing naturally in milk or inoculated as starters in fermented dairy products. Recent research suggests that fermented dairy products are a cocktail of bioactive ingredients. The objective of our study was to evaluate the bioactivity of cell wall fractions of Lactobacillus and Bifidobacterium grown in reconstituted skimmed milk, and the possibility of intra- and extracellular extracts of these bacteria for applications in foods and beyond. Intracellular and extracellular extracts of Lactobacillus and Bifidobacterium showed inhibitory activities against food and dermal pathogens. All strains were able to produce inhibitors, such as organic acids, antimicrobial peptides, diacetyl, and hydrogen peroxide. Most strains showed higher production of extracellular than intracellular inhibitors $(\mathrm{P}<0.05)$. Meanwhile, all strains were able to produce hyaluronic acid, lipoteichoic acid, peptidoglycan, neutral sphingomyelinase and acid sphingomyelinase at concentrations applicable for cosmeceutical application. Findings from our study demonstrated that inhibitors and bioactives from lactobacilli and bifidobacteria have the potential to be developed into formulations for food and non-food applications.
\end{abstract}

Keywords: lactobacilli, bifidobacteria, inhibitors, bioactives, cosmeceutical, foods

Lactobacilli and bifidobacteria are among the most common genera associated with probiotic properties, isolated from raw milk and fermented dairy products (FAO/WHO, 2006). These bacteria have been well documented for their gastrointestinal health benefits of a variety of fermented foods. In parallel, emerging clinical studies suggest that probiotics in foods might exert their benefits beyond the gut, extending to non-food applications, including cosmeceuticals. This motivates researchers alike to investigate the functionality and potential of these bacteria in foods and cosmeceutical applications.

Milk provides nutrient rich medium for the growth of probiotics, thereby various inhibitors and bioactives are produced and subsequently accumulated in the growth medium upon milk fermentation. Lactobacillus and Bifidobacterium rapidly produce desirable inhibitors that exert strong antagonistic activity against food-borne pathogens, and thus widely applicable to food industries. These inhibitors include organic acids, antimicrobial peptides, diacetyl, and hydrogen peroxide $\left(\mathrm{H}_{2} \mathrm{O}_{2}\right)$. Organic acids have been used for decades as food additives for preventing food deterioration. Antimicrobial peptides have also received increasing attention as biopreservatives to inhibit competitive microflora, particularly in cheese. Furthermore, diacetyl and $\mathrm{H}_{2} \mathrm{O}_{2}$ can also contribute to the overall antagonistic activity against food-borne pathogens. Meanwhile, current studies have postulated the use of inhibitors from lactobacilli and bifidobacteria beyond food applications. The beneficial effects derived from bioactives produced by these bacteria, such as hyaluronic acid (HA),

\footnotetext{
* To whom correspondence should be addressed.

Phone: +604 653 2114; fax: +604 657 3678; e-mail: mintze.liong@usm.my
} 
peptidoglycan (PG), lipoteichoic acid (LTA), and sphingomyelinase, may strengthen the skin defence system. However, limited studies have been carried out to evaluate such potentials. Thus, the aim of our present study is to evaluate the ability of Lactobacillus and Bifidobacterium grown in reconstituted skimmed milk to produce compounds that are inhibitive against food and dermal pathogens, and beneficial for skin health.

\section{Materials and methods}

\subsection{Bacterial cultures}

Klebsiella pneumoniae, Escherichia coli, Staphylococcus aureus, S. epidermidis, Micrococcus luteus, Pseudomonas aeruginosa, and Streptococcus pyogenes were obtained from the culture collection of Bioprocess Division, School of Industrial Technology, Universiti Sains Malaysia (USM) (Penang, Malaysia). These bacteria were grown in trypticase soy broth (Hi media, India), except for M. luteus, which was grown in nutrient broth (Merck, Germany), at $37^{\circ} \mathrm{C}$ for $18 \mathrm{~h}$. Pure cultures of Lactobacillus casei BT 0442 and BT 1268, L. plantarum FTDC 8943, L. fermentum BT 8848, BT 8219, FTDC 8513 and FTDC 8312, L. acidophilus FTDC 2333, FTDC 4356, and FTDC 314, L. bulgaricus FTDC 8611 and FTDC 8913, Bifidobacterium longum FTDC 8643 and FTDC 8843, and B. bifidum FTDC 2142 were obtained from the culture collection of Bioprocess Division, School of Industrial Technology, USM (Penang, Malaysia). All strains were activated successively three times in de Man Rogosa Sharpe (MRS) broth (Hi media, India) at $37^{\circ} \mathrm{C}$ for $24 \mathrm{~h}$ prior to use. Sterile MRS broth supplemented with $0.15 \%(\mathrm{w} / \mathrm{v})$ L-cysteine hydrochloride was used for the propagation of Bifidobacterium.

\subsection{Determination of cell growth and $p H$}

Activated cell cultures of $1 \%(\mathrm{v} / \mathrm{v})$ of Lactobacillus or Bifidobacterium were inoculated into $8 \%(\mathrm{w} / \mathrm{v}) \mathrm{RSM}$ and fermented at $37^{\circ} \mathrm{C}$. Bacterial growth in RSM at $0,4,8,12,16,20$, and $24 \mathrm{~h}$ were determined via the pour plate method. Strains that presented statistically higher growth in the stationary phase were selected for further analyses.

Activated cell cultures of $1 \%(\mathrm{v} / \mathrm{v})$ of Lactobacillus or Bifidobacterium were inoculated into $8 \%(\mathrm{w} / \mathrm{v}) \mathrm{RSM}$ and fermented for $20 \mathrm{~h}$. $\mathrm{pH}$ was determined using DELTA $320 \mathrm{pH}$ meter.

\subsection{Preparation of extracellular and intracellular extracts and cell wall fractions}

Cells were collected by centrifugation $(12000 \times g)$ for 15 min at $4{ }^{\circ} \mathrm{C}$. The supernatant was designated as extracellular extract. The pellet obtained was suspended in PBS buffer (pH 7.4) and sonicated $(20 \mathrm{kHz})$ in an ice bath for 15 min prior to centrifugation. The supernatant and pellet obtained were designated as intracellular extract and cell wall fraction, respectively. All samples were stored at $-20{ }^{\circ} \mathrm{C}$ prior to the determination of inhibitors and bioactives.

\subsection{Determination of extracellular and intracellular antimicrobial activities}

The antimicrobial activities were determined using the disc diffusion method, based on the diameter of the inhibition zone around each paper disc. The unfermented RSM and fermented RSM treated with heat $\left(140{ }^{\circ} \mathrm{C}, 10 \mathrm{~min}\right)$ were used as control and negative control, respectively. 


\subsection{Determination of inhibitive compounds}

Concentrations of organic acids were determined by High Performance Liquid Chromatography (HPLC). HPLC was equipped with a UV absorbance detector set at $220 \mathrm{~nm}$. Chromatographic separation was performed on a Luna C18 (2) column (Phenomenex, USA). The degassed mobile phase $\left(25 \mathrm{mM} \mathrm{KH}_{2} \mathrm{PO}_{4}, \mathrm{pH}\right.$ 2.5: methanol, 97:3) was used at a flow rate of $0.3 \mathrm{ml} \mathrm{min}^{-1}$. HPLC-grade acetic and lactic acids (Sigma-Aldrich, Germany) were used as standard.

Crude antimicrobial peptides were precipitated using ammonium sulphate. Antimicrobial peptides were quantified using Bradford method with bovine serum albumin (SigmaAldrich, Germany) as standard. The absorbance of samples was measured at $595 \mathrm{~nm}$.

$\mathrm{H}_{2} \mathrm{O}_{2}$ was determined using the spectrophotometric method (JuAREZ \& ElENA, 2004). $\mathrm{H}_{2} \mathrm{O}_{2}$ (Merck, Germany) was used as standard and absorbance of samples was measured at $430 \mathrm{~nm}$.

Concentrations of diacetyl were determined based on the colorimetric reaction with creatine and $\alpha$-naphthol. Diacetyl (Sigma-Aldrich, Germany) was used as standard and absorbance of samples was measured at $525 \mathrm{~nm}$.

\subsection{Determination of bioactives}

Hyaluronic acid (HA) was determined using the cetyltrimethylammonium bromide turbidimetric method. Purified HA (Sigma-Aldrich, Germany) was used as standard, and absorbance of samples was measured at $400 \mathrm{~nm}$.

Sphingomyelinase activities were studied using Amplex ${ }^{\circledR}$ Red sphingomyelinase assay kit (Invitrogen, United Kingdom). The fluorescence of samples was measured at an emission of $590 \mathrm{~nm}$ and excitation of $540 \mathrm{~nm}$.

Concentrations of LTA were determined using LTA enzyme-linked immunosorbent assay (ELISA). A standard curve of LTA was made by using purified LTA of Staphylococcus aureus (Sigma-Aldrich, Germany). Absorbance of samples was measured at $450 \mathrm{~nm}$.

Concentrations of PG were determined using human PG ELISA kit (Ruiqi Biological Technology, China). Absorbance of samples was measured at $450 \mathrm{~nm}$.

\subsection{Statistical analysis}

All data were analysed by SPSS Inc. software version 15 (SPSS Inc., USA). One-way analysis of variance was performed to analyse the difference between sample means. The statistical level of significance was set at $\alpha=0.05$. The multiple means comparison was assessed by Tukey's test. All data presented were mean values of triplicates, obtained from three separate runs.

\section{Results and discussion}

\subsection{Growth and $\mathrm{pH}$}

All fifteen strains were able to grow and reached exponential phase at $8 \mathrm{~h}$ to $16 \mathrm{~h}$ and stationary phase after $20 \mathrm{~h}$ (data not shown). All strains recorded maximum viable counts ranging between 7.93 and $10.19 \log _{10} \mathrm{CFU} \mathrm{ml}^{-1}$. Although strains grew well in RSM, most of the inhibitors and bioactives were accumulated maximally in the cultured medium during the stationary phase (TAN et al., 2011). In order to further elucidate the ability of Lactobacillus and Bifidobacterium in exhibiting beneficial effects on dermal health, L. plantarum BT 8943, 
L. fermentum FTDC 8312 and BT 8848, B. longum FTDC 8643, and L. casei BT 1268 that showed higher growth in RSM $(\mathrm{P}<0.05)$ during the stationary phase $(20 \mathrm{~h})$ were selected for subsequent analyses.

Our current data showed that the $\mathrm{pH}$ of RSM inoculated with Lactobacillus or Bifidobacterium decreased $(\mathrm{P}<0.05)$ upon fermentation at $37^{\circ} \mathrm{C}$ for $20 \mathrm{~h}$ (Table 1). These strains have the ability to excrete protons leading to a decrease in the $\mathrm{pH}$ of RSM upon fermentation (TSENG et al., 1991). RSM fermented by L. fermentum FTDC 8312 had a smaller decrease $(0.55$ units $)$ in $\mathrm{pH}$ compared to other strains $(\mathrm{P}<0.05)$, and would change concentration of $\mathrm{H}^{+}$by a factor of 3.55. Organic acids are proton donors, leading to the lowering in the $\mathrm{pH}$ of the surroundings. However, L. fermentum FTDC 8312 produced a lower amount of extracellular acetic acid compared to other strains $(\mathrm{P}<0.05$; Table 2$)$; thereby a smaller change in $\mathrm{pH}$ of RSM was observed. Although B. longum FTDC 8643 is not a lactic acid bacteria as the other Lactobacillus spp., a significant change in the pH of RSM was observed $(\mathrm{P}<0.05)$. Some strains of bifidobacteria are facilitated by specific $\mathrm{ABC}$ transporters and glycosyl hydrolases, thus resulting in a greater production of organic acids and a greater drop in the $\mathrm{pH}$ of milk (PoKUSAEVA et al., 2011).

Table 1. Changes in $\mathrm{pH}$ of $8 \%(\mathrm{w} / \mathrm{v}) \mathrm{RSM}$ prior and upon fermentation by Bifidobacterium and Lactobacillus for $20 \mathrm{~h}$

\begin{tabular}{|c|c|c|c|}
\hline \multirow{3}{*}{ Strain } & \multicolumn{3}{|c|}{$\mathrm{pH}_{\text {value }}{ }^{1}$} \\
\hline & \multicolumn{2}{|c|}{ Time (h) } & \multirow[b]{2}{*}{$\Delta\left[\mathrm{H}^{+}\right]$factor } \\
\hline & 0 & 20 & \\
\hline L. plantarum BT 8943 & $5.70 \pm 0.00^{\mathrm{aA}}$ & $4.75 \pm 0.21^{\mathrm{dB}}$ & $8.91^{\mathrm{a}}$ \\
\hline L. fermentum BT 8848 & $5.70 \pm 0.00^{\mathrm{aA}}$ & $4.85 \pm 0.07^{\mathrm{bB}}$ & $7.08^{\mathrm{b}}$ \\
\hline B. longum FTDC 8643 & $5.65 \pm 0.07^{\mathrm{aA}}$ & $4.80 \pm 0.00^{\mathrm{cB}}$ & $7.08^{\mathrm{b}}$ \\
\hline L. casei BT 1268 & $5.30 \pm 0.00^{\mathrm{aA}}$ & $4.75 \pm 0.07^{\mathrm{dB}}$ & $7.08^{\mathrm{b}}$ \\
\hline L. fermentum FTDC 8312 & $5.30 \pm 0.00^{\mathrm{aA}}$ & $5.05 \pm 0.07^{\mathrm{aB}}$ & $3.55^{\mathrm{c}}$ \\
\hline
\end{tabular}

${ }^{1}$ Results are expressed as mean \pm standard deviation $(n=3)$. ${ }^{\text {abcd }}$ Means in the same column with different lowercase superscript letters are significantly different $(\mathrm{P}<0.05)$. ${ }^{\mathrm{AB}}$ Means in the same row with different uppercase superscript letters are significantly different $(\mathrm{P}<0.05)$

\subsection{Intracellular and extracellular antimicrobial activities}

In order to be used as food preservatives or components in skin care products, Lactobacillus and Bifidobacterium are required to specifically inhibit the growth of foodborne and dermal pathogens. Intracellular and extracellular extracts from all strains showed inhibitory activities against $K$. pneumoniae, $P$. aeruginosa, E. coli, and $S$. aureus, which are important causative agents in food poisoning. In addition, intra- and extracellular extracts from all strains also inhibited $S$. pyogenes and $M$. luteus that are commonly associated with skin wounds. Intracellular extract of $L$. case $i$ BT 1268 showed greater inhibitory activity against $E$. coli and $P$. aeruginosa compared to other strains $(\mathrm{P}<0.05)$, with the inhibition zone ranging from $8.10-9.25 \mathrm{~mm}$. However, it was less effective against $M$. luteus compared to other pathogens $(\mathrm{P}<0.05)$. Meanwhile, L. fermentum FTDC 8312 showed a greater extracellular antimicrobial activity against $S$. epidermidis, $M$. luteus, and $P$. aeruginosa compared to the other strains $(\mathrm{P}<0.05)$, with the inhibition zone ranging from $8.25-10.00 \mathrm{~mm}$. 
Table 2. Concentration of inhibitive compounds from intracellular and extracellular extracts of Bifidobacterium and Lactobacillus upon fermentation in $8 \%(\mathrm{w} / \mathrm{v}) \mathrm{RSM}$ for $20 \mathrm{~h}$

\begin{tabular}{|c|c|c|c|}
\hline \multirow[b]{2}{*}{ Strain } & \multicolumn{3}{|c|}{ Concentrations, $\mathrm{mg} \mathrm{ml}^{-1}$} \\
\hline & $\begin{array}{l}\text { Intracellular } \\
\text { (I) }\end{array}$ & $\begin{array}{l}\text { Extracellular } \\
\text { (E) }\end{array}$ & $\begin{array}{c}\text { Difference, } \\
(\mathrm{E}-\mathrm{I}) / \mathrm{E} \times 100(\%)\end{array}$ \\
\hline \multicolumn{4}{|l|}{ Acetic acid } \\
\hline L. plantarum BT 8943 & $0.779 \pm 0.146^{\mathrm{aB}}$ & $2.413 \pm 0.266^{\mathrm{aA}}$ & 67.72 \\
\hline L. fermentum BT 8848 & $0.378 \pm 0.151^{\mathrm{bB}}$ & $2.292 \pm 0.171^{\mathrm{aA}}$ & 83.51 \\
\hline B. longum FTDC 8643 & $0.821 \pm 0.121^{\mathrm{aB}}$ & $2.496 \pm 0.171^{\mathrm{aA}}$ & 67.11 \\
\hline L. casei BT 1268 & $0.381 \pm 0.124^{\text {ьв }}$ & $1.561 \pm 0.248^{\mathrm{bA}}$ & 75.59 \\
\hline L. fermentum FTDC 8312 & $0.351 \pm 0.921^{\mathrm{bB}}$ & $2.107 \pm 0.289^{\mathrm{abA}}$ & 83.34 \\
\hline \multicolumn{4}{|l|}{ Antimicrobial peptides } \\
\hline L. plantarum BT 8943 & $0.351 \pm 0.226^{\mathrm{aB}}$ & $0.581 \pm 0.090^{\mathrm{aA}}$ & 39.59 \\
\hline L. fermentum BT 8848 & $0.300 \pm 0.167^{\mathrm{aB}}$ & $0.432 \pm 0.189^{\mathrm{bA}}$ & 30.55 \\
\hline B. longum FTDC 8643 & $0.211 \pm 0.193^{\text {ьв }}$ & $0.440 \pm 0.322^{\mathrm{bA}}$ & 52.05 \\
\hline L. casei BT 1268 & $0.320 \pm 0.506^{\mathrm{aB}}$ & $0.571 \pm 0.360^{\mathrm{aA}}$ & 43.96 \\
\hline L. fermentum FTDC 8312 & $0.320 \pm 0.174^{\mathrm{aA}}$ & $0.381 \pm 0.417^{\mathrm{bA}}$ & - \\
\hline \multicolumn{4}{|l|}{ Diacetyl } \\
\hline L. plantarum $\mathrm{BT} 8943$ & $0.787 \pm 0.424^{\mathrm{cB}}$ & $3.167 \pm 0.448^{\text {bcA }}$ & 75.15 \\
\hline L. fermentum BT 8848 & $1.086 \pm 0.279^{\mathrm{cB}}$ & $2.432 \pm 0.382^{\mathrm{cdA}}$ & 55.35 \\
\hline B. longum FTDC 8643 & $1.164 \pm 0.279^{\mathrm{cB}}$ & $2.354 \pm 0.336^{\mathrm{dA}}$ & 50.55 \\
\hline L. casei $\mathrm{BT} 1268$ & $7.090 \pm 0.810^{\mathrm{aB}}$ & $9.343 \pm 0.323^{\mathrm{aA}}$ & 24.11 \\
\hline L. fermentum FTDC 8312 & $5.436 \pm 1.109^{\mathrm{bA}}$ & $3.797 \pm 0.305^{\mathrm{bA}}$ & - \\
\hline
\end{tabular}

Results are expressed as mean \pm standard deviation $(\mathrm{n}=3$ ). abcd Means in the same column with different lowercase superscript letters are significantly different $(\mathrm{P}<0.05)$. ${ }^{\mathrm{AB}}$ Means in the same row with different uppercase superscript letters are significantly different $(\mathrm{P}<0.05)$. - Means no significant difference and/or intracellular $>$ extracellular. Control (unfermented milk) and negative control (heat treated fermented RSM): not detected

\subsection{Inhibitive compounds}

Organic acids have a long history of use as food additives and/or accumulate as a consequence of the addition of starter culture in dairy products prior to the fermentation process. Organic acid sprays have also been utilized as sanitizers in meat processing, where there is a potential of being contaminated with foodborne pathogens. In the current study, a notable amount of organic acids, such as lactic and acetic acids; were detected in both intracellular and extracellular extracts of all strains. Concentrations of lactic and acetic acids in the extracellular extract were $79 \%$ and $67 \%$ higher, respectively, than intracellular extracts of all strains $(\mathrm{P}<0.05)$. Lactobacillus and Bifidobacterium produce lactic and acetic acids inside the cell, and transport them out from the cell through the cellular membrane to maintain intracellular homeostasis (SuRviLA et al., 2011). While extracellular extracts from strains of Lactobacillus and Bifidobacterium contained equal concentrations of lactic acid (data not shown), the concentration of extracellular acetic acid from B. longum FTDC 8643 was $37.4 \%$ higher than from L. casei BT 1268 ( $\mathrm{P}<0.05$; Table 2). The presence of fructose-6-phosphoketolase in $B$. longum FTDC 8643 allows the former to ferment carbohydrates and produced more acetic 
acid via the bifidus pathway. Lactic and acetic acids are strong inhibitors of most Gramnegative and neutrophilic bacteria, such as $S$. aureus. The inhibitory activities of these acids have been associated with the ability to dissociate and release high amount of free $\mathrm{H}^{+}$in a relative low acid stress environment, resulting in the membrane disruption of pathogenic bacteria. Our study demonstrated that all strains produced lactic acid at concentrations of $0.2-0.4 \%(\mathrm{w} / \mathrm{v})$. Lactic acid was shown to modulate the barrier function of stratum corneum (BERARDESCA et al., 1997). Topical application of $0.5 \%$ acetic acid was also shown to eliminate $P$. aeruginosa from the burn wounds of patients (SLOss et al., 1993). Although a higher concentration of acetic acid is required to eliminate $P$. aeruginosa, inhibitory action against $P$. aeruginosa could be increased via synergism with lactic acid (TANNER \& JAMES, 1992). Summing it up, the preliminary findings in this study suggest that concentrations of lactic and acetic acids produced would be sufficient for food and cosmeceutical applications.

Antimicrobial peptides are ribosomally synthesized proteinaceous metabolites that exert antimicrobial actions against closely related bacteria. Application of antimicrobial peptides in foods reduces the intensity of heat treatment needed and could result in foods which are richer in nutrition values. Theoretically, bacteria produce antimicrobial peptides as an extracellular inhibitive complex. This was in agreement with our current data (Table 2), where higher concentrations were observed from extracellular extracts compared to the intracellular extracts $(\mathrm{P}<0.05)$. Lactobacillus and Bifidobacterium have been well documented to produce antimicrobial peptides which exhibit broad antimicrobial spectrum towards closely related Gram-positive bacteria. Other than food applications, topical application of $3.15 \%$ antimicrobial peptides was shown to eliminate dermal pathogens (Он et al., 2006). In our current study, Lactobacillus and Bifidobacterium were able to produce antimicrobial peptides at a lower concentration, ranging from $0.3-0.6 \mathrm{mg} \mathrm{ml}^{-1}$. These concentrations may not be sufficient to exert inhibitive actions, but inhibitory efficiency was reportedly increased via synergism with organic acids. Most of the antimicrobial peptides from Lactobacillus and Bifidobacterium interfere with anionic lipids in the membrane structure, thus initiating the formation of pores and resulting in increased permeability in the cytoplasmic membrane of susceptible cells.

$\mathrm{H}_{2} \mathrm{O}_{2}$ is a food preservative, with short lived actions against foodborne pathogens at refrigeration temperatures. Its beneficial role in food applications has been demonstrated in dairy industries, as improving the hygiene of dairy products. Most of the strains produced equal concentrations of $\mathrm{H}_{2} \mathrm{O}_{2}$ in both intra- and extracellular extracts (data not shown). Our present study has also shown that $L$. casei BT 1268 produced higher concentration of $\mathrm{H}_{2} \mathrm{O}_{2}$ compared to the other strains $(\mathrm{P}<0.05)$. Lactobacillus strains including L. casei, possess specific metabolic enzymes including $\mathrm{NADH}$ peroxidase, pyruvate and lactate oxidase, which aid a higher production of $\mathrm{H}_{2} \mathrm{O}_{2}$ (BARRE et al., 2007). $\mathrm{H}_{2} \mathrm{O}_{2}$ has the ability to increase membrane permeability, of denaturing metabolic enzymes, and of oxidizing lipids in the membrane layer of pathogens. All strains produced $\mathrm{H}_{2} \mathrm{O}_{2}$ at concentrations ranging from $0.005-0.03 \%$. It has been reported that $\mathrm{H}_{2} \mathrm{O}_{2}$ at a concentration as low as $0.01 \%$ inhibited bacterial skin infections (OMIDBAKHSH, 2011). Thus, concentrations of $\mathrm{H}_{2} \mathrm{O}_{2}$ produced by strains in the present study could be sufficient to exert such an effect.

Diacetyl is a low molecular mass structure, which is excreted out from the cell and accumulated in the growth medium without alteration of the membrane layer. Diacetyl has been used as dairy flavouring and biopreservative in a variety of foods, such as cheese and yogurt. All strains produced varying concentrations of diacetyl (Table 2), where a higher concentration was detected in the extracellular extract than in the intracellular extract 
$(\mathrm{P}<0.05)$. Diacetyl can be synthesized via intermediary $\alpha$-acetolactate, transported out from the cell, and leading to a higher concentration of diacetyl detected in the extracellular extract. Additionally, the presence of specific citrate transporters in Lactobacillus also facilitates the production of diacetyl (Quintas et al., 2008). This was in tandem with our results, where higher concentrations of diacetyl were produced by Lactobacillus spp. compared to B. longum FTDC $8643(\mathrm{P}<0.05)$. Diacetyl has been shown to inhibit E. coli and $S$. aureus via the inhibition of arginine utilization in the periplasmic space. Our results showed that all strains were able to produce diacetyl at concentrations ranging from $2.0-10.0 \mathrm{mg} \mathrm{ml}^{-1}$. Diacetyl is effective against Gram-negative bacteria at concentrations as low as $0.2 \mu \mathrm{g} \mathrm{ml}^{-1}$ (WILLIAMsChampbell, 1998). Thus, the concentrations of diacetyl produced by all strains could exert effective inhibition against foodborne and dermal pathogens.

\subsection{Bioactives}

Hyaluronic acid (HA) has been used as an ideal bio-component in dermatological applications. The application of cosmetic products containing HA could enhance moisture locking functions. Lactobacillus strains and B. longum FTDC 8643 were able to produce HA (Fig. 1A). HA is produced intracellularly, where two UDP-activated sugars are catalyzed by hyaluronan synthase within the cytosol. HA formed is then transported to the extracellular matrix via $\mathrm{ABC}$ transporters. This was in tandem with our current data, where most of the strains showed higher production of HA in the extracellular extract compared to the intracellular extract $(\mathrm{P}<0.05)$. The transport efficiency of cellular membrane has a greater influence on the release of intracellular HA(VAN DE RIJN, 1983). Thus, varying concentrations of HA observed in Lactobacillus strains and B. longum FTDC 8643 could be due to the different degrees of transport efficiency in the cellular membrane. HA at a concentration as low as $10 \mu \mathrm{g} \mathrm{ml}^{-1}$ reportedly increased the production of proinflammatory cytokines TNF- $\alpha$ and IL-8 during the early stage of wound healing process (BROwN \& JONES, 2005). Therefore, it is postulated that the concentrations of HA produced by our strains $\left(0.3-0.7 \mathrm{mg} \mathrm{ml}^{-1}\right)$ could be sufficient to provide possible dermal benefits.

Sphingomyelinase is a sphingomyelin-specific phospholipase $\mathrm{C}$ that catalyzes the hydrolysis of sphingomyelin to generate phosphocholine and ceramide. Ceramides are major structural components in the horny layer, and play a fundamental role in providing the cutaneous permeability barrier function. All strains exhibited both neutral sphingomyelinase (N-SMase) and acid sphingomyelinase (A-SMase) activities. Extracellular SMase activities was higher than that of intracellular SMase activities $(\mathrm{P}<0.05)$. SMase localized within cells and can be secreted out to the extracellular space, generating a higher level of extracellular SMase activity. Lactobacillus casei BT 1268 exhibited higher N-SMase activity compared to the other strains $(\mathrm{P}<0.05$; Fig. 1B), whereas all strains exhibited equal A-SMase activity (data not shown). Although N-SMase activity varies among strains, L. casei is one of the Lactobacillus spp. capable of presenting a higher level of N-SMase activity (Di MARzIo et al., 2001). C24- and C16-ceramides could also be generated by the activation of both N-SMase and A-SMase. SMase at a concentration as low as $1.0 \mathrm{mU} \mathrm{ml}^{-1}$ increased ceramide formation and induced interleukin 6 production in human fibroblasts (STANLEY et al., 1995). All strains exhibited both N-SMase and A-SMase activities, with concentrations ranging from 0.4-0.6 $\mathrm{mU} \mathrm{ml} \mathrm{m}^{-1}$ and $0.1-2.4 \mathrm{mU} \mathrm{ml}^{-1}$, respectively. We believe these concentrations could be sufficient to promote beneficial dermal effects. 
A

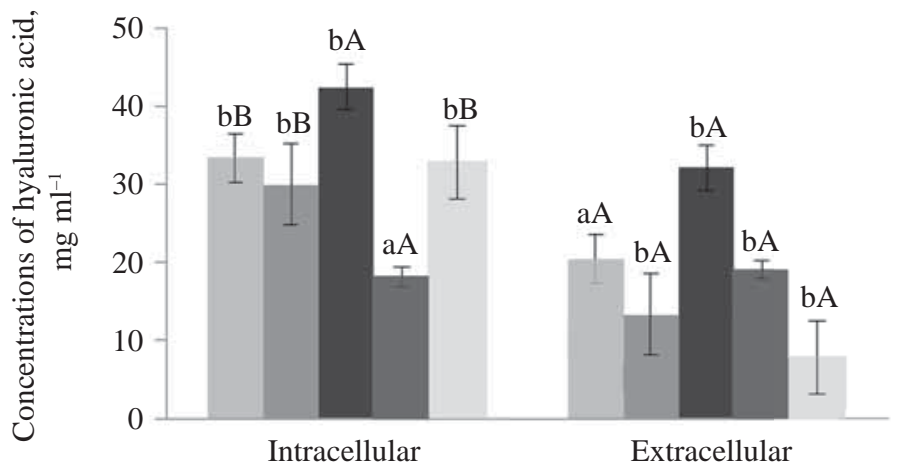

Extracts

B

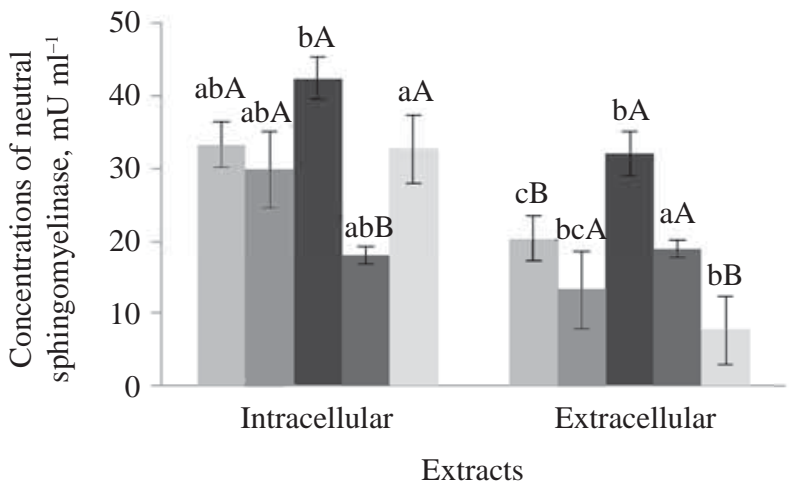

C

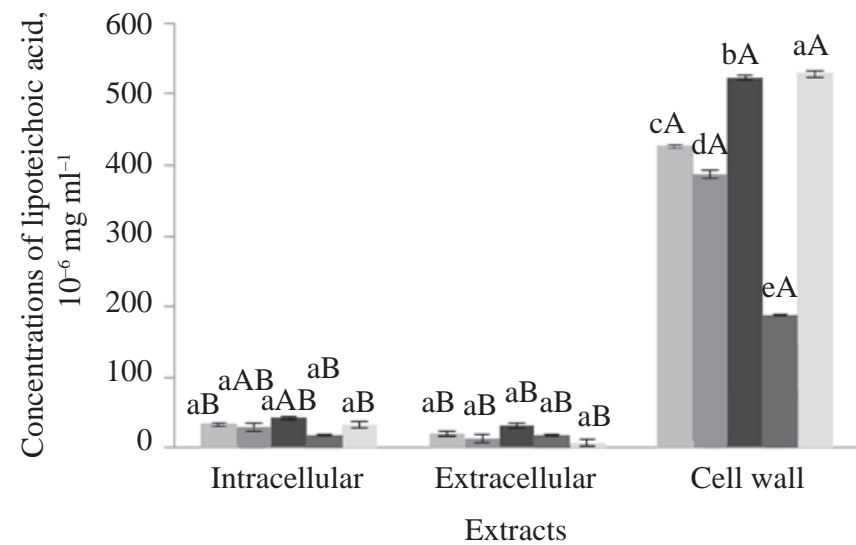

Fig. 1. Concentration of bioactives in extra- and intracellular extracts and cell wall fraction of Bifidobacterium and Lactobacillus upon fermentation in $8 \%(\mathrm{w} / \mathrm{v}) \mathrm{RSM}$ at $37^{\circ} \mathrm{C}$ for $20 \mathrm{~h}$. A. Hyaluronic acid. B. Neutral sphingomyelinase activity C. Lipoteichoic acid. abcde Means in the same series with different lowercase superscript letters are significantly different $(\mathrm{P}<0.05)$. ${ }^{\mathrm{AB}}$ Means in the same category with different uppercase superscript letters are significantly different $(\mathrm{P}<0.05$ ). Control (unfermented milk) and negative control (heat treated fermented RSM): not detected. $\square$ : L. plantarum BT 8943; $\square$ : L. fermentum BT 8848;

$\square$ : B. longum FTDC 8643; $\square$ : L. casei BT 1268; $\square$ : L. fermentum FTDC 8312. 
LTA is present exclusively in the cell wall of Gram-positive bacteria that contributes to inflammatory and immune homeostasis on skin. LTA from $S$. epidermidis inhibited IL-8 and IL-1 $\alpha$ production of keratinocytes, and inflammation triggered by TLR2-dependent injuries. LTA has also been demonstrated as a stimulatory component for the expression of human beta defensin-2 (hBD-2), which could strengthen the skin defence system. Lactobacillus strains and B. longum FTDC 8643 showed varying concentrations of LTA in the cell wall fraction, and in extracellular and intracellular extracts (Fig. 1C). Despite being the abundant component present in the cell wall of Gram-positive bacteria, LTA can also be released spontaneously into the culture medium during growth (PoLlack et al., 1992). This agreed with our current data, where higher concentration of LTA was detected in the cell wall fraction, with smaller amounts detected in both extracellular and intracellular extracts $(\mathrm{P}<0.05)$. Production of LTA was strain dependent. L. fermentum FTDC 8312 contained a significantly higher concentration of LTA in the cell wall fraction compared to the other strains $(\mathrm{P}<0.05)$. Little information is available on the biosynthesis of LTA from Lactobacillus and Bifidobacterium. However, L. fermentum ATCC 14931 possess dlt operon containing $d l t \mathrm{D}$ (EMBL source EEI22757.1) that is essential for D-alanylation during LTA biosynthesis (DeBABov et al., 2000). Although this may be strain specific, we postulate that L. fermentum FTDC 8312 may possess the gene encoding dltD leading to increased production of LTA. More work is needed to justify this finding. Our current study demonstrated that all strains produced LTA at concentrations of $180-530 \mathrm{ng} \mathrm{ml}^{-1}$. LTA at a concentration as low as $100 \mathrm{ng}$ $\mathrm{ml}^{-1}$ increased the stimulation of antimicrobial peptides in human epithelial cells (NEUMAN et al., 2010). Additionally, LTA from Lactobacillus had low cytotoxicity compared to LTA isolated from pathogenic bacteria. Therefore, the concentrations of LTA produced by our strains would be sufficient and safe for the expression of human $\beta$-defensins and may subsequently contribute to enhance skin defence.

PG from bacteria has been reported to induce hBD-2 expression in skin cells. PG is one of the pathogen-associated molecular patterns that results in an induction of defence-related genes and elevation of the barrier function in epidermal keratinocytes. All strains contained equal amounts of PG in the cell wall fraction, despite the differences in genera (data not shown). Furthermore, a lower concentration of PG was also detected in both extra- and intracellular extracts. This may be due to the acid-insoluble PG turnover that was released into the culture medium via lytic activity (FREHEL \& RYTER, 1979). Our strains were able to produce $\mathrm{PG}$ at concentrations ranging from 300 to $410 \mathrm{ng} \mathrm{ml}^{-1}$. PG at a lower concentration of $2.5 \mu \mathrm{g} \mathrm{ml}^{-1}$ increased the expression of the LL37 in keratinocytes, leading to a protective effect in psoriatic skin lesions (RuIz-GonZALEz et al., 2009). Although a higher concentration of PG is required to stimulate the cellular immunity response and LL37 in keratinocytes, an induction response has been reported via synergism with LTA. Considering that our strains produced PG and LTA at concentrations ranging from 180 to $530 \mathrm{ng} \mathrm{ml}^{-1}$, we postulated that this concentration could exert a stimulative cellular immunity response for skin defence.

\section{Conclusion}

Results illustrated the potential use of cell wall fractions and intra- and extracellular extracts of lactobacilli and bifidobacteria grown in milk, as inhibitors and/or bioactives for food and cosmeceutical applications. All strains were able to produce inhibitors and bioactives at 
concentrations that could inhibit the growth of bacteria that cause food-borne illnesses and dermal infections, and improve cellular immunity responses needed for skin defence.

This work was financially supported by the Science Fund Grant (305/PTEKIND/613222) provided by the Malaysian Ministry of Science, Technology and Innovation (MOSTI), the USM RU Grant (1004/PTEKIND/815085) provided by Universiti Sains Malaysia (USM), the FRGS grant (203/PTEKIND/6711239) and the MyPhD scholarship provided by the Malaysian Ministry of Higher Education (MOHE).

\section{References}

Barre, O., Mourlane, F. \& Solioz, M. (2007): Copper induction of lactate oxidase on Lactococcus lactis: a novel metal stress response. J. Bacteriol., 189, 5947-5954.

Berardesca, E., Distante, F., Vigonoli, G.P. \& Oresajo, C. (1997): Alpha hydroxyl acids modulate stratum corneum barrier function. Br. J. Dermatol., 137, 934-938.

Brown, M.B. \& Jones, S.A. (2005): Hyaluronic acid: a unique topical vehicle for the localized delivery of drug to the skin. J. Eur. Acad. Dermatol. Venereol., 19, 308-321.

Debabov, D.V., Micheal, Y.\& Neuhaus, F.C. (2000): Biosynthesis of lipoteichoic acid in Lactobacillus rhamnosus: role of DltD in D-alanylation. J. Bacteriol., 182, 2855-2864.

Di Marzio, L., Russo, F.P. \&Amicosante, G. (2001): Apoptotic effects of selected strains of lactic acid bacteria on a human $\mathrm{T}$ leukemia cell line are associated with bacterial arginine deiminase and/or sphingomyelinase activities. Nutr. Cancer, 40, 185-196.

FAO/WHO (2006): Evaluation of health and nutritional properties of probiotics in food including powder milk with live lactic acid bacteria: Report of a Joint FAO/WHO Expert Consultation (Online). (Accessed 10 July 2012). Available at: http://www.who.int/foodsafety/publications/fs_management/en/probiotics.pdf.

Frehel, C.\& Ryter, A. (1979): Peptidoglycan turnover during growth of a Bacillus megaterium Dap-Lys-mutant. J. Bacteriol., 137, 947-955.

JuAreZ, T.M. \& Elena, N.M. (2004): Production of antimicrobial substance in lactic acid bacteria I: determination of hydrogen peroxide. Methods Mol. Biol., 268, 337-346.

Neuman, M.G., Oruna, L., Coto, G.\&Vincent, M. (2010): Hyaluronic acid signals for repair in ethanol-induced apoptosis in skin cells in vitro. Clin. Biochem., 43, 822-826.

Он, S., Kiм, S.H., Ko, Y.\& LeE, S.H. (2006): Effect of bacteriocin produced by Lactococcus sp. HY 449 on skininflammatory bacteria. Fd Chem. Toxicol., 44, 1184-1190.

Омidвakhsh, N.O. (2011): Hydrogen peroxide-based skin disinfectant. US Patent Application. Publication US 2011/0129435 A1.

Pokusaeva, K., Fitzgerald, G.F.\&Van Sinderen, D. (2011): Carbohydrate metabolism in bifidobacteria. Genes Nutr., 6, 285-306.

Pollack, J.H., Ntamere, A.S. \& Neuhaus, F.C. (1992): D-alanyl-lipoteichoic acid in Lactobacillus casei: secretion of vesicles in response to benzyl penicillin. J. Gen. Microbiol., 138, 849-859.

Quintas, N.G., Blancato, V., Repizo, G.\& Magni, C. (2008): Citrate metabolism and aroma compound production in lactic acid bacteria. -in: Mayo, B., LóPez, P. \& Pérez-Martinez, G. (Eds): Molecular aspects of lactic acid bacetria for traditional and new applications. Research Signpost, India, pp. 65-88.

Ruiz-Gonzalez, V., Cancino-Diaz, C.J., Rodeiguez-Martinez, S.R.\& Cancino-Diaz, E.C. (2009): Keratinocytes treated with peptidoglycan from Staphylococcus aureus produce vascular endothelial growth factor, and its expression is amplified by the subsequent production of interleukin-13. Int. J. Dermatol., 48, 846-854.

Sloss, J.M., Cumberland, N.\& Milner, S.M. (1993): Acetic acid used for the elimination of Pseudomonas aeruginosa from burn and soft tissue wounds. J. R. Army Med. Corps, 139, 49-51.

Stanley, J., Laulederkind, F., Bielawska, A. \& Raghow, R. (1995): Ceramide induces interleukin 6 gene expression in human fibroblasts. J. Exp. Med., 182, 599-560.

Survila, A., Kanapeckaite, S., Pileckiene, J.\& Budiene, J. (2011): Kinetics of hydrogen evolution on copper electrode involving organic acids as proton donors. Int. J. Electrochem., 2011, 1-9.

Tan, C.L., Ning, S.P. \& Boey, P.L. (2011): Detection of bioactive compound from Spilantesacmella (L.) plants and its various in vitro culture products. J. Med., Plant Res., 5, 371-378. 
TANNER, R.S.\& JAmes, S.A. (1992): Rapid bactericidal effect of low pH against Pseudomonas aeruginosa. J. Ind. Microbiol. Biotechnol., 10, 229-232.

Tseng, C.P., Tsau, J.L.\& Montville, T.J. (1991): Bioenergetic consequences of catabolic shifts by Lactobacillus plantarum in response to shift in environmental oxygen and $\mathrm{pH}$ in chemostat culture. J. Bacteriol., 173, 4411-4416.

VAN DE Ruj, I. (1983): Streptococcal hyaluronic acid: proposed mechanisms of degradation and loss of synthesis during stationary phase. J. Bacteriol., 156, 1059-1065.

Williams-Champbell, A.M. (1998): Studies on the mode of action of diacetyl and carbon dioxide as inhibitors of meat spoilage bacteria. (Accessed on 18 June 2012). http://digitalcommons.wayne.edu/dissertations/ AA19827248. 